\title{
Who Can Refinance? The Possibilities and Limitations of Market-based Refinancing in the Case of Mortgages with a Variable Interest Rate*
}

\author{
Bálint Dancsik - Nedim Márton El-Meouch
}

In our study we examine what portion of variable interest rate mortgages can be profitably and realistically refinanced on a market basis, in the light of remaining maturity, the current one-off costs of refinancing and the prevailing interest rate spread. To that end, relying on microdata we applied various methods (from using the simple banking sector average spread to applying a linear regression model) to estimate the interest rate spread at which debtors would be able to take out a new, variable-rate loan. If the estimated spread of the new loan is adequately low, refinancing may be a financially rewarding option for the debtor. According to our results, 22-31 per cent of the variable interest rate mortgage loans disbursed prior to 2015 could be refinanced in this way assuming conservative lending conditions. Although we focused on the refinancing of variable-rate loans with other variablerate loans directly, our results also indicate that on a market basis, there may be limited room for refinancing variable-rate loans with fixed-rate loans and hence, for mitigating the interest rate risk of the household sector. In our opinion, by easing the obstacles to loan refinancing, the recommendation of the Magyar Nemzeti Bank on interest rate risk may considerably raise the share of debtors switching to fixed-rate loans.

Journal of Economic Literature (JEL) codes: D14, E43, G21, G41

Keywords: mortgage loan, variable interest rate, interest rate risk, loan refinancing

\section{Introduction and motivation}

The post-crisis history of the Hungarian financial system demonstrates that a rise in borrowers' debt service can stretch debtors' financial position and this can easily become a problem for the banking sector as well via the increase in credit risk. Although the conversion of FX-denominated retail mortgages to HUF in the

\footnotetext{
* The papers in this issue contain the views of the authors which are not necessarily the same as the official views of the Magyar Nemzeti Bank.
}

Bálint Dancsik is a Senior Economist at the Magyar Nemzeti Bank. E-mail: dancsikb@mnb.hu Nedim Márton El-Meouch is a Junior Analyst at the Magyar Nemzeti Bank.E-mail: elmeouchn@mnb.hu

The Hungarian manuscript was received on 8 March 2019.

DOI: http://doi.org/10.33893/FER.18.2.530 
first quarter of 2015 eliminated debtors' exchange rate risk, under the relevant legislation lending rates were tied to the 3-month interbank rate; consequently, instalments remained volatile in many cases. ${ }^{1}$ Apart from FX loans converted to HUF, there are also other loans outstanding with variable interest rates: a significant portion of the housing loans disbursed in the first few years following the demise of foreign currency lending was extended with an interest rate fixation of less than 1 year up until 2018, after which the expansion of loans with an interest rate fixation of over 1 year became unquestionable. ${ }^{2}$ Between 2010 and 2018, loans extended by credit institutions with an interest rate fixation of less than 1 year amounted to HUF 1,369 billion, and banks' on-balance sheet stock of loans converted to HUF

Figure 1

Share of fixed-rate mortgages in loans outstanding vs. in new contracts

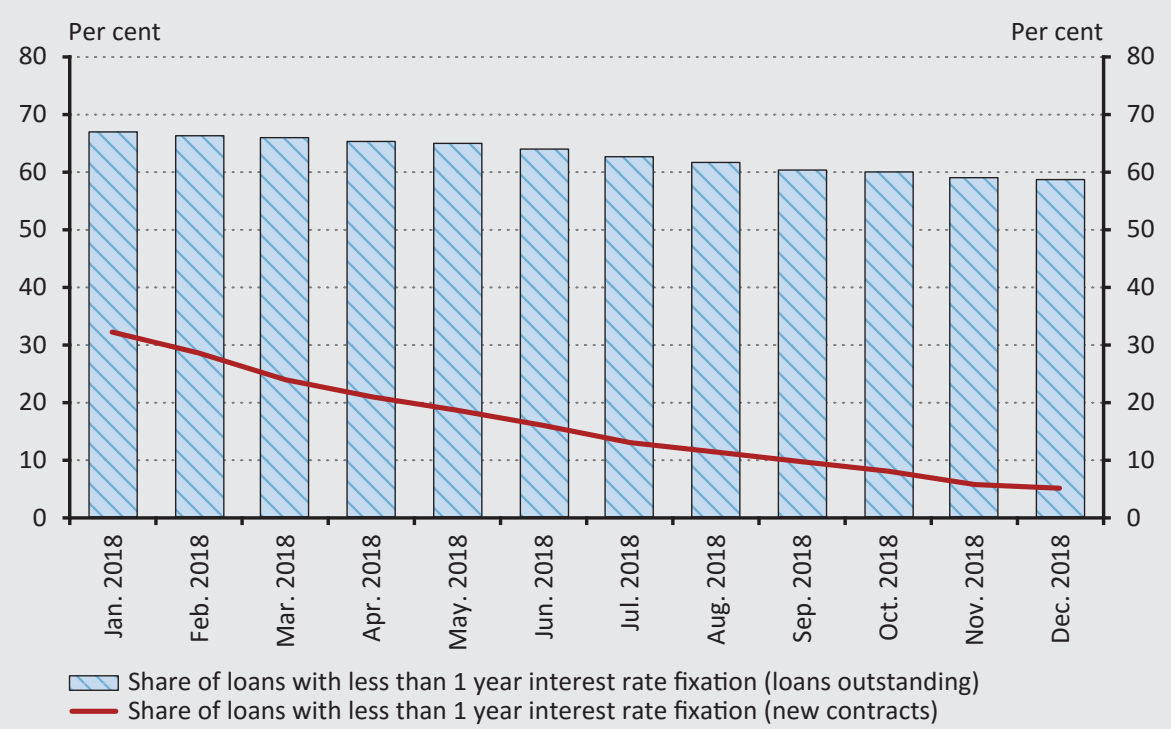

Note: Shares are calculated on the basis of volume. In the case of new contracts, shares were calculated based on newly disbursed housing loans, while for loans outstanding it was based on all mortgage loans (housing loans and home equity loans together).

Source: MNB

\footnotetext{
${ }^{1}$ While in this way the Conversion Act exposed debtors to interest rate risk, had it provided otherwise - i.e. had it prescribed a fixed rate - the conversion would have caused a shock-like surge in banks' interest rate risk. The hedging requirement of this conversion would have induced a large-scale, simultaneous, same-direction demand in the interest rate derivative market, which would have also raised the price of interest rate swaps. The Act, however, enabled debtors to refinance their debt at reduced costs (even with fixed-rate loans), although only a marginal percentage of borrowers (around 1.5 per cent) took advantage of this opportunity.

${ }^{2}$ While the share of variable-rate loans in new contracts ranged between 40 and 45 per cent in the period of 2015-2017, this ratio shrank to 15 per cent in 2018 as a whole. By December 2018, 95 per cent of newly disbursed housing loans had an initial interest rate fixation of over 1 year. Contracts with an initial interest rate fixation of 1-5 years represented 26 per cent, while 57 per cent and 12 per cent of new housing loans were disbursed with an initial interest rate fixation of 5-10 years and over 10 years, respectively.
} 
still exceeds HUF 1,200 billion. Therefore, although loans extended with an interest rate fixation of over 1 year now account for a considerable share of newly disbursed mortgages, with a stock of HUF 2,500 billion and a share of nearly 60 per cent, the outstanding portfolio is still dominated by variable-rate loans (Figure 1).

In the case of variable-interest loans indexed to the short-term reference interest rate, a rise in the interest rate environment will quickly increase the amount of the debt service as well. The percentage of this increase depends primarily on remaining maturity: the longer the remaining maturity, the larger the rise in the instalment in response to one unit of interest rate increase. An interest rate increase of 100 basis points raises instalments by around 3 per cent in the case of a loan with a remaining maturity of 5 years, whereas this increment reaches 5 per cent for a 10-year loan and almost 9 per cent for a loan with a remaining maturity of 20 years. The effect of an interest rate increase also depends on the current interest rate level (the lower the current interest rate, the larger the effect of a unit increase in the rate), but its impact is far less significant than that of the remaining maturity. ${ }^{3}$

A considerable portion of the variable interest rate mortgage portfolio is still characterised by relatively long remaining maturities. More than half of the loans have a remaining maturity of over 10 years (Figure 2). Consequently, the normalisation of monetary policy - that is, departure from the near-zero interest environment - may raise the debt service of many households in the period ahead. This risk can be reduced significantly by the long-term fixation of interest rates, but this comes at a price: in the light of the normal yield curve, the current value of the long-term fixed interest rate is higher than the value of floating interest rates indexed to the reference rate, which are subject to short-term adjustments. ${ }^{4}$ The customer primarily pays for the hedging cost of banks' interest rate risk - in other words, the difference between the short-term interbank interest rate and the interest rate swap corresponding to the duration of the interest rate fixation and reflecting market expectations about rate changes - assuming that the spread applied by the bank does not differ significantly in the case of these two product types. ${ }^{5}$

\footnotetext{
${ }^{3}$ Obviously, loans with an interest rate fixation for longer periods - but not for the entire term of the loan also involve an interest rate risk, as the loan is repriced at the end of the interest period. With an interest rate hike like this the debtor may even face a potentially greater shock because, as opposed to floatingrate loans, the rate increase takes place in a concentrated, rather than a gradual, manner. Rate-sensitivity, however, is mitigated by the fact that, on the one hand, the transaction's remaining maturity can decrease significantly by the end of the interest period and, on the other hand, in the event of interest rate changes detrimental to the debtor, the customer is entitled to early prepayment free of charge.

${ }^{4}$ Based on data for new contracts as at December 2018, weighted by contracted amount the Annual Percentage Rate of Charge (APRC) of housing loans with an interest rate fixation of less than 1 year was 3.33 per cent. The APRC was 4.49 per cent for loans with an interest rate fixation of $1-5$ years, 5.22 per cent in the case of 5-10 year fixation and 5.66 per cent over 10 years.

${ }^{5}$ Based on the data, however, banks set substantially different spreads for these two product types for a long time; in other words, the spreads on loans with an initial interest rate fixation of over 1 year were higher than justified (Aczél et al. 2016; MNB 2017). This discrepancy could be observed up until 2018, when the two spreads converged (MNB 2018b).
} 


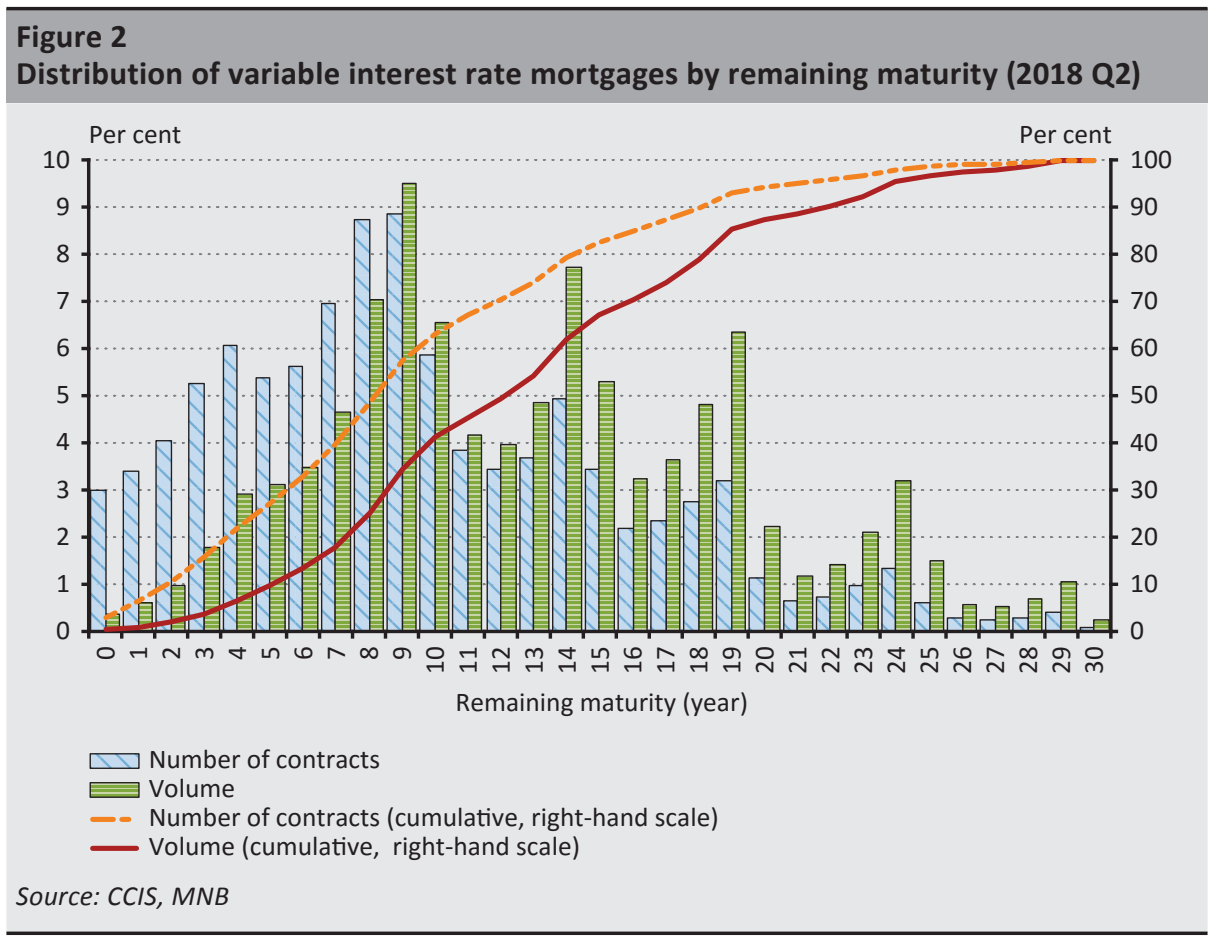

As a method of averting interest rate risk, debtors can opt to refinance their variable-rate debt with fixed-rate loans. The focal question of our research is to determine the extent to which the share of fixed-rate loans in loans outstanding can be increased on a market basis through refinancing. Although the interest rate structure of new loans suggests that the portfolio is increasingly shifting to loans with a longer-term interest rate fixation virtually "by itself" in any event, in terms of proportions, this shift can only be a slow and gradual process due to the size of the portfolio. Under the current circumstances, the share of loans with interest rate fixation of over 1 year in the total portfolio edges upward by $0.5-1$ percentage point on a monthly basis on average. This rate may accelerate if a larger volume of new (fixed-rate) loans was taken out for the purpose of the early repayment of previous (variable-rate) loans. Our study is motivated by the following question: how much room is available for debtors to replace their variable-rate loans with fixed-rate loans on a market basis? 
Whether or not it is worth it for a debtor to refinance a variable-rate mortgage loan with a fixed-rate loan is an extremely complex question, which depends, first and foremost, on the following:

(1) the size of the spread over the funding cost corresponding to the interest rate fixation in the case of the two products,

(2) the one-off costs of the refinancing,

(3) the debtor's risk sensitivity; i.e. the "utility" attributed by the debtor to constant instalments,

(4) the debtor's interest rate expectations which may differ from the market expectations reflected in the price of interest rate swaps,

(5) the debtor's financial awareness or lack thereof, which may deter the debtor from loan refinancing even if the debtor has the necessary financial means.

The data at our disposal do not allow us to address all of these aspects. Our study is focused primarily on the first and second aspects, and attempts to assess loan refinancing options from a pricing point of view. Our specific research question is the following: how many variable-rate mortgage contracts could be replaced by another variable-rate mortgage contract in such a way that the gain stemming from the lower interest rate spread offsets the one-off costs of the refinancing during the remaining maturity? Although we rely on the database of variable-rate loans for our estimation with spreads being the main focus of the estimate, the ratio thus received may also serve as an indication of the breadth available for refinancing debts with fixed-rate loans on a market basis. Of course, by extending our results we implicitly assume that (1) the debtor's interest rate expectations are identical with market expectations; in other words, (2) the debtor is willing to pay the difference in funding costs, and (3) the bank is willing to disburse variable-rate and fixed-rate refinancing loans at the same spread.

Our paper is structured as follows: Section 2 provides a brief overview of the main findings of the relevant literature. In Section 3, we discuss in detail the way in which the profitability of loan refinancing can be determined; in Section 4 we describe the data and methodology used, while the results of our estimates are presented in Section 5. Finally, Section 6 provides a summary of our conclusions. 


\section{Findings of the relevant literature}

The literature on this topic raises a number of questions. Some of these focus on the decision-making situation of households, while the rest explore the macroeconomic consequences of the interest rate risk and the interest type. From the perspective of households, the present value of refinancing is determined by four factors (Follain - Tzang 1988): (1) the one-off costs of refinancing, i.e. the early repayment fee of the old loan and the administrative costs of the new loan, (2) the duration for which the debtor wishes to hold his mortgage loan (for practical purposes, the remaining maturity), (3) the difference between the interest rates of the old and the new loan, and (4) the tax implications of the early repayment fee and the interest payments. ${ }^{6}$ In making their decision, households need to weigh two questions: firstly, whether the present value of the gain to be achieved by refinancing is positive (i.e. whether the lower cash flows of the refinancing loan will compensate for the costs of refinancing) and secondly, whether, at the given moment, this present value is at its maximum, or they are better off waiting somewhat longer before they refinance (Agarwal et al. 2016). The latter aspect is important because even if the present value of the refinancing is positive, by opting for refinancing the borrower loses the option of refinancing at a more optimal rate after waiting longer. Several studies pointed out that borrowers do not make rational decisions in refinancing situations and are prone to making both potential mistakes: on the one hand, they may miss refinancing opportunities even though they could gain from the transaction (Bajo - Barbi 2018); on the other hand, they often choose to refinance at a sub-optimal time (Chang - Yavas 2009; Agarwal et al. 2016). ${ }^{7}$

It is important to stress that the earlier literature typically attempts to gauge the optimal time at which it is worthwhile to refinance a fixed-rate loan with another fixed-rate loan. This question raises far fewer problems than trying to determine the optimal time for refinancing a variable-rate transaction with a fixed-rate transaction, as the borrower's risk sensitivity plays a prominent role in the latter case, but this is a hard-to-observe variable. In the case of new loans, households' choice between variable and fixed rates typically reveals the bounded rationality of the participants. The literature found that households do not act prudently when assessing risks, and their decisions are far more likely to be determined by the prevailing interest

\footnotetext{
${ }^{6}$ In some countries, interest payments and the early repayment fee can be deducted from the taxes paid by the debtor, which may influence the decision-making situation. In Hungary, however, interest payment has no such tax implications.

${ }^{7}$ Numerous studies have been published on the calculation of the optimal refinancing rate; however, they have less relevance for our research question which is more of an economic policy nature. For a comprehensive overview of the theoretical models, see the studies by Agarwal et al. (2013) and Agarwal et al. (2016).
} 
rate differential between the two product types ${ }^{8}$ (Koijen et al. 2009; Ehrmann Ziegelmayer 2014; Badarinza et al. 2018; Basten et al. 2018), rather than by the size of the cash flows expected throughout the loan term. However, as mentioned in the introduction, we refrain from addressing these questions in this specific estimate.

The issue of interest type is all the more relevant as the interest type typical of mortgage loans has a significant impact on the balance sheet of the banking sector. For instance, euro area banks operating in countries with predominantly fixedrate mortgages banks typically undertake higher interest risks; i.e. they do not fully hedge their interest rate risk exposures (ECB 2018; Hoffmann et al. 2018). Therefore, although households are protected from the effects of interest rate hikes in these countries, for banks, an interest rate increase entails a decline in the profits generated by mortgage loans. Albertazzi et al. (2018) also highlight the importance of the level of development of the capital market: the share of fixed-rate loans is typically higher in countries with a more advanced institutional structure for long-term, fixed-rate borrowing. Basten et al. (2018), in turn, found that banks' pre-existing interest rate risk exposure also strongly influences the lending rates of fixed and variable-rate loans: when banks see their target level of interest rate risk reached or exceeded, they try to steer their customers to product types that allow the banks to reduce their risks, either by adjusting their lending rates or offering shorter (or longer) fixation periods than those preferred by the customer.

The interest rate structure of loans also affects the functioning of monetary policy transmission (Calza et al. 2013). In countries characterised by a higher share of variable rates, monetary policy exerts a stronger influence on real economic developments. Ippolito et al. (2018) confirm this by demonstrating, through outstanding corporate loans, that owing to the floating rates, monetary policyinduced changes affect firms' investment decisions and liquidity faster. The study refers to this phenomenon as the floating rate channel.

\section{Estimating the gain achievable by refinancing}

In this study, our goal is to select loans from outstanding variable-rate mortgages where refinancing could be a financially rewarding and realistic option. In constructing our model for refinancing, we examined the refinancing of loans with another, variable-rate mortgage in the light of the data available. In our analysis, we weighed and compared against each other two main criteria:

\footnotetext{
${ }^{8}$ This trend may also reflect the fact that - for the lack of certainty regarding future information - upon the calculation of the annual percentage rate of charge (APRC) it is assumed in the case of variable-rate products that the initial borrowing rate remains unchanged throughout the whole lifespan of the loan, which is almost certain to underestimate the actual costs when the yield curve is normal (Berlinger 2017).
} 
- firstly, the debtor bears one-off costs, which are charged in relation to the new borrowing and to the early repayment of the old loan,

- secondly, the future expected cash flows of the new loan are different from the expected cash flows of the old loan. The difference between the present value of the two cash flows shows the debtor's gain (or potential loss) stemming from refinancing.

The above can be summed up as follows:

$$
P V=-C_{\text {refinancing }}+\sum_{t=1}^{n} \frac{\left(C_{t, \text { old }}-C_{t, \text { new }}\right)}{\left(1-r_{t}\right)^{t}}
$$

where $P V$ is the present value of refinancing, $C_{\text {refinancing }}$ is the initial costs, $C_{t, \text { old }}$ and $C_{t, \text { new }}$ are the cash flows stemming from the old and the new loan at date $t$, respectively, $r_{t}$ is the discount rate prevailing in period $t$ (which equals the product of forward yields between period 1 and $t$ ), and $n$ denotes the number of the remaining periods.

If the gain stemming from the difference between the cash flows (instalments) exceeds the one-off costs of refinancing, the present value of the transaction will be positive.

The positive difference can be primarily explained by the spread decline achievable during the term of the loan by way of the refinancing loan. If the refinancing loan has a lower spread, the longer the remaining maturity of the loan, the greater the gain thus received. In the case of loans with short remaining maturities, the gain realised by the customer from the difference in debt services is insufficient to "cover" the one-off costs. Therefore, remaining maturity and the gains from refinancing are positively correlated.

Obviously, the gain achievable depends on the one-off costs of refinancing. If the refinancing process is free of charge ${ }^{9}$ even the smallest spread decline will make the refinancing profitable; by contrast, high one-off costs would require a greater spread decline for the transaction to be profitable. In other words, the level of one-off costs and the potential gain are negatively correlated.

\footnotetext{
${ }^{9}$ Of course, owing to the non-negligible administrative requirements of refinancing (according to MNB $2018 a$ the time requirement of refinancing is around 30-40 days), non-monetary "costs" are incurred even in this case, but these are disregarded in our analysis.
} 
Some of the one-off costs (early repayment fee, disbursement charge, notary fee) depend on the amount of the early repayment/new borrowing, while another part (land registry fee, lien registration) is independent of it (Table 1). Due to the nominally fixed costs, in the case of larger contracted amounts even a smaller spread decrease compensates for one-off costs. Accordingly, the amount of the outstanding debt and the gain from refinancing are also positively correlated.

\section{Table 1}

Cost types incurred in 2019 in Hungary for refinancing

\begin{tabular}{|c|c|c|}
\hline Description of cost & Cost amount & Bank discount is typical \\
\hline $\begin{array}{l}\text { Submission of sales contract to the land } \\
\text { registry }\end{array}$ & HUF 11,100 & No \\
\hline Valuation of property & HUF 30,000 & Yes \\
\hline Issuance of notarial deed & HUF 50,000-150,000 & Yes \\
\hline Lien registration & HUF 17,100 & No \\
\hline Disbursement & $\begin{array}{l}1 \text { per cent of the disbursed } \\
\text { amount }\end{array}$ & Yes \\
\hline Early repayment/Prepayment & $\begin{array}{l}1 \text { per cent of the early } \\
\text { repayment amount }\end{array}$ & No \\
\hline Total costs (for a loan of HUF 10 million) & HUF 393,000 & - \\
\hline
\end{tabular}

Note: For the issuance of the notarial deed we used individual, contract-level notary fees, but we did not detail them in the table due to the complexity of the calculation method (staggered fee charged as a function of the basic amount and the contracted amount, lump sum cost). For the purposes of the calculations we applied notary fees planned to be effective from 1 July 2019 (after the repeated prolongation of the fee changes).

Source: MNB

In order to illustrate the correlations described above, we constructed a number of indifference curves (Figure 3). The indifference curves show by how much should the spread decrease at the minimum to make refinancing at various refinancing costs and under stipulated credit terms (HUF 10 million outstanding principal amount, 2.8 per cent spread) worthwhile for borrowers in the case of loans with given maturities. Therefore, the points displayed on the indifference curve by and large meet the following condition:

$$
C_{\text {refinancing }}=\sum_{t=1}^{n} \frac{\left(C_{t, \text { old }}-C_{t, \text { new }}\right)}{\left(1-r_{t}\right)^{t}}
$$




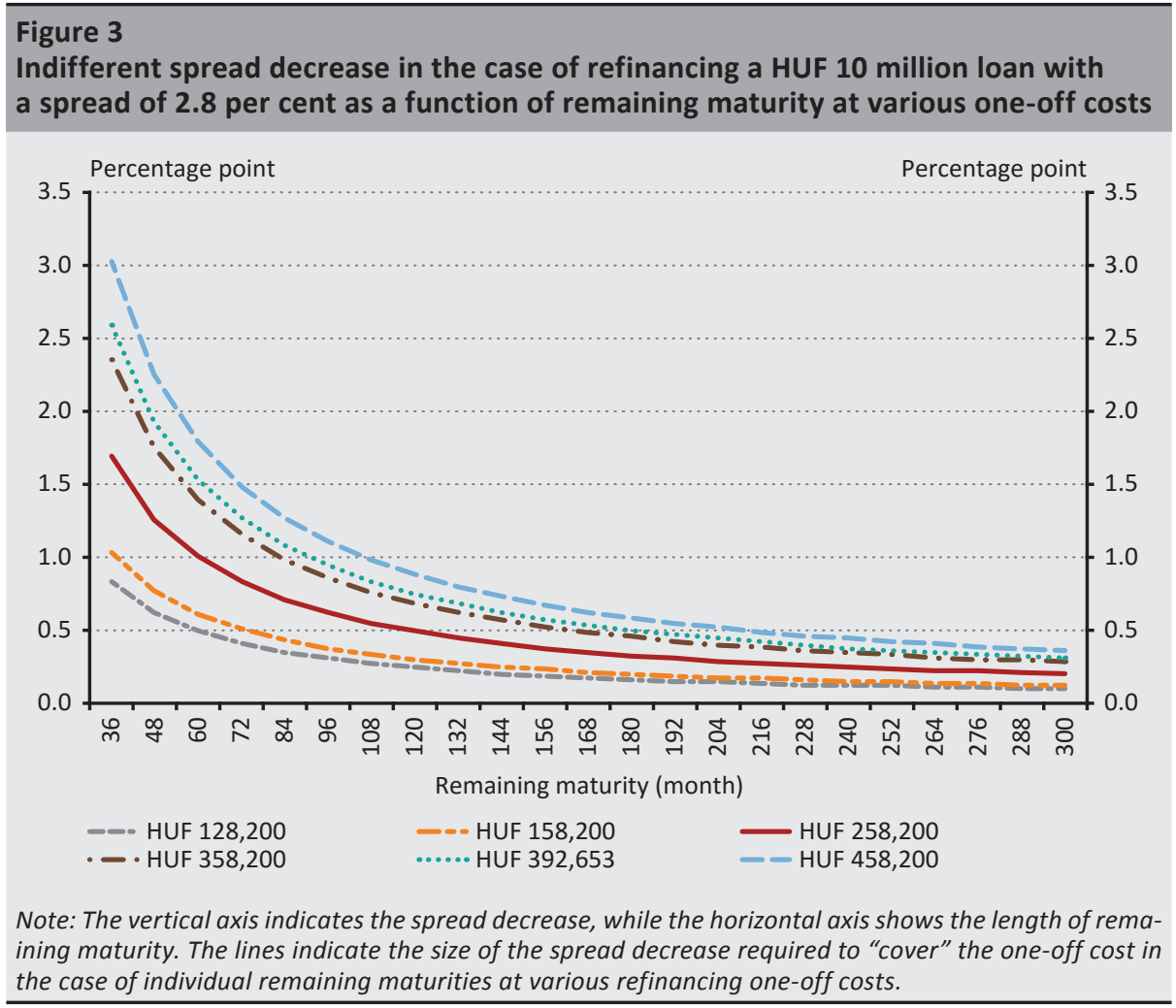

Calculating the present value or "gain" described above would be far more difficult if we were to assess the refinancing of variable-rate loans with fixed-rate loans. While in the case of a variable rate-variable rate or fixed-rate-fixed-rate refinancing transaction a change in the interest rate exerts a similar impact on the cash flows of the old and the new loan and thus the difference remains approximately constant, in comparing variable and fixed-rate loans we must reckon with the possibility of unexpected interest rate shocks and the level of the debtor's risk aversion or risk appetite, i.e. the extent to which the debtor wishes to avoid the effects of unexpected interest rate shocks. ${ }^{10}$

Since we have no information on debtors' risk appetite, we did not analyse this issue directly. For the purposes of our estimate, we essentially examined whether the borrower of a variable-rate loan could refinance his loan with another variable-

\footnotetext{
${ }^{10}$ For instance, in the case of mortgage loans disbursed prior to 2018, the spread of loans with an interest rate fixation of over 1 year over the IRS was far higher than the spread of floating-rate loans over the shortterm interbank interest rate. This suggests that Hungarian households were willing to pay a premium in exchange for the constancy of the instalments, which may also reflect the negative experiences gained in relation to foreign currency borrowing (Dancsik 2017).
} 
rate loan in a financially rewarding way. ${ }^{11}$ However, in our opinion (and also in consideration of the implicit assumptions emphasised in the introductory section), the results of our estimates can be also interpreted extensively: if, based on our estimate, the borrower can take out such a variable-rate loan, then he can also have access to a fixed-rate loan with a similar spread and accordingly, he can potentially reduce his interest rate risk by way of refinancing. This extension assumes a neutral risk appetite on average, which means that, in exchange for hedging their interest rate risk, borrowers are only willing to pay the market price of the hedging (i.e. the difference between IRS and BUBOR, the Budapest Interbank Offered Rate). With this, if the customers are risk averse we underestimate, and if they are risk-takers we overestimate the effective refinancing possibilities. Although the previous high spread of fixed-rate loans indicates that customers are willing to pay a premium for safety (i.e. they are risk averse), Hungarian financial culture is also prone to overrate immediate advantages. The latter inclination suggests that borrowers choose the product that comes with a currently lower instalment amount, which may be indicative of a - not necessarily conscious - risk-taking attitude. It is therefore difficult, overall, to determine the direction of the bias arising from the extension of our estimate due to the assumption of risk neutrality.

In view of the above, our estimation strategy is the following:

1. We calculate the current spreads of the variable-rate loans disbursed between 2004 and $2014 .{ }^{12}$ In order to do so, we needed to estimate the handling charges applied by banks in the case of loans disbursed in the period 2004-2009; ; $^{13}$

2. On a sample of the variable-rate loans disbursed between 2015 and 2018 we estimate the spread that is currently typical for loans with various features. As part of this step, we estimate the partial effect exerted on the spread by the factors shaping the spread of recently disbursed loans;

\footnotetext{
${ }^{11}$ The previous, excessively high spread set for loans with an interest rate fixation of over a year over the funding cost is another reason why we should not include these loans in the estimate. Indeed, if these loans were included in our sample, in our estimate the size of the refinancing spreads would be overestimated compared with the actual situation.

${ }_{12}$ We did not estimate spreads for variable-rate mortgage loans disbursed after 2015 as we assumed that the actual spread captures reality better than any value that we could have estimated regarding the specific contract.

${ }^{13}$ Although we have contract-level data available pertaining to the current interest rates, contracts for the loans converted to forint were concluded on the basis of a previous version of the Act on Consumer Credit that is no longer effective; therefore, costs over and above the interest rate also constitute a part of the debt service. The most important of these are handling charges - a non-negligible item in the practice of most banks. In the first step of the estimate, we adjusted the interest rates for the handling charges, for which we took into account the service charges specified in the List of Conditions of the ten largest banks for the no longer disbursed, FX- (and HUF-) denominated mortgage loans. Inevitably, our estimate reflects some bias due to the fact that the actual handling charges may differ for each contract type even within the same bank (e.g. normal or preferential handling charges or loans without handling charges). Moreover, we also assume that, despite the handling charge categories specified in the List of Conditions, banks may have deviated from those values at the transaction level, which gives rise to further bias in our estimate.
} 
3. Based on certain features of the loans disbursed between 2004 and 2014 and using the coefficients/spreads estimated as described above, we estimate the spread at which these loans could be refinanced today;

4. We examine whether the difference between the current spread and the estimated spread of the refinancing loan would be sufficient to compensate for the borrower's one-off refinancing costs during the remaining maturity of the transaction;

5. Finally, we also examine potential grounds for exclusion (previous nonperformance, high age, high loan-to-value ratio, low income) which may prevent the refinancing transaction.

It is also important to stress that our calculations show only and exclusively the number of contracts worth refinancing from a financial perspective on a market basis under the prevailing regulations. This is far from stating that the borrowers concerned (1) are even aware of this option, and (2) are willing to take advantage of it. As we mentioned in the introduction, after the conversion of foreign currency loans to forint, borrowers were given an option to refinance their loans fully exempted from paying the early repayment fee, but the value of refinancing contracts only amounted to HUF 45 billion at the end of 2015, which accounts for a negligible 1.5 per cent of the potential stock. ${ }^{14}$ Thus our estimates by no means reflect our expectations about future refinancing volumes; they much rather point out that - given that a considerable portion of the variable-rate loans have short remaining maturities, low principal amounts and/or low spreads - we cannot expect debtors to switch their contracts to fixed-rate contracts without any external incentive for a significant part of the portfolio.

\section{Data and methodology}

For the purposes of this study, we relied on databases that contain contract level data on the household loan contracts carried on the balance sheets of credit institutions. We had access to 2018 Q2 data recorded in the Central Credit Information System (CCIS), to which we linked anonymised credit risk data from the MNB's data supply coded L11 (payment-to-income ratio, loan-to-value ratio) and data from the personal income tax returns provided by the National Tax and Customs Administration.

Before the analysis, we excluded outliers and presumably inaccurate values from our database to prevent significant bias to our estimates. For the exclusion of outliers from the database, we used the 1st and 99th percentile as a benchmark in the case of most variables. As a result of these exclusions and due to the data

\footnotetext{
${ }^{14}$ Bajo - Barbi (2018) described a similar phenomenon in Italy: although the one-off costs associated with refinancing were practically cancelled in full in 2007, the share of borrowers taking recourse to refinancing was only 13 per cent 8.5 years after the modification.
} 
that were unavailable from the start, our analysis - which did not include income and co-debtor statuses - covered 361,252 mortgage loan contracts, while our methodologies that also processed the former data categories were developed on the basis of 288,893 observations. ${ }^{15}$ In all cases, we projected our final results to the total dataset and accordingly, the results show the refinanceability ratio and other distributions relative to a total of 379,852 contracts for variable-rate mortgages disbursed in the period 2004-2014. ${ }^{16}$

We estimated the spread of the refinancing loans on the sample of variable-rate mortgage loans disbursed between 2015 Q1 and 2018 Q2, which was constructed on the basis of 77,713 contracts in the case of the smallest banking sector sample. In Table 2 and Table 3, the descriptive statistics of the variables used are broken down by date of disbursement: on the one hand, for the loans disbursed in the period 2004-2014 - which comprised the dataset analysed - and, on the other hand, for the loans disbursed between January 2015 and July 2018, which played a role in the determination of the refinancing interest rate spread. In the former case, the variable values as at end-June 2018, while in the latter case the values prevailing at the contract date bore relevance.

\begin{tabular}{|c|c|c|c|c|c|c|}
\hline \multicolumn{7}{|c|}{$\begin{array}{l}\text { Table } 2 \\
\text { Descriptive statistics of the variables pertaining to the variable-rate mortgage loan } \\
\text { contracts disbursed in 2004-2014 }\end{array}$} \\
\hline Variable & Number & Mean & Median & $\begin{array}{l}\text { Standard } \\
\text { deviation }\end{array}$ & Minimum & Maximum \\
\hline Spread* & 364,949 & 4.56 & 4.36 & 1.74 & 0.07 & 15 \\
\hline $\begin{array}{l}\text { Indifference spread } \\
\text { differential }\end{array}$ & 358,748 & 4.75 & 1.47 & 10.02 & 0.20 & 59.25 \\
\hline $\begin{array}{l}\text { Outstanding } \\
\text { principal amount }\end{array}$ & 379,852 & $4,534,396$ & $3,142,305$ & $4,860,102$ & 1 & $99,300,000$ \\
\hline Remaining maturity & 377,095 & 9.46 & 8.85 & 5.62 & 0.003 & 31.60 \\
\hline Income by co-debtor & 302,749 & $3,211,436$ & $2,594,197$ & $2,320,615$ & 166,256 & $25,000,000$ \\
\hline Co-debtor & 329,557 & 0.48 & 0 & 0.50 & 0 & 1 \\
\hline Age** $^{* *}$ & 329,557 & 46.05 & 45 & 8.46 & 12 & 89 \\
\hline Contract type $e^{* * *}$ & 381,130 & 0.48 & 0 & 0.50 & 0 & 1 \\
\hline
\end{tabular}

*Adjusted for service charges in the case of contracts concluded in the period 2004-2009.

**Where the transaction involved co-debtors, we used the average age of the debtor and the co-debtors for our calculations.

***For the purposes of contract type, 0 means housing loan and 1 means home equity loan contracts.

\footnotetext{
${ }^{15}$ In the case of contracts concluded in 2004-2009, the number of contracts included in the analysis was reduced further by the fact that we adjusted the spreads for service charges for the ten largest banks only.

${ }^{16}$ All this entailed 237,819 and 187,167 observations, respectively, in the individual analyses of loans converted to forint; in their case the total dataset under review comprised 250,525 observations, and we scaled our results and distributions to this statistical population.
} 


\begin{tabular}{|c|c|c|c|c|c|c|}
\hline \multicolumn{7}{|c|}{$\begin{array}{l}\text { Table } 3 \\
\text { Descriptive statistics of the variables pertaining to the variable-rate mortgage loan } \\
\text { contracts disbursed between January } 2015 \text { and June } 2018\end{array}$} \\
\hline Variable & Number & Mean & Median & $\begin{array}{l}\text { Standard } \\
\text { deviation }\end{array}$ & Minimum & Maximum \\
\hline Spread & 88,959 & 3.38 & 2.91 & 1.32 & 0.08 & 15 \\
\hline Contracted amount & 87,751 & $7,925,319$ & $6,500,000$ & $5,544,318$ & 150,043 & $30,000,000$ \\
\hline Original maturity & 89,251 & 15.85 & 15.05 & 6.59 & 1.02 & 31.00 \\
\hline Income by co-debtor & 79,602 & $3,984,491$ & $3,124,783$ & $2,956,716$ & 200,105 & $25,000,000$ \\
\hline Co-debtor & 83,939 & 0.53 & 1 & 0.50 & 0 & 1 \\
\hline Age* & 83,939 & 39.60 & 39 & 8.89 & 16 & 83 \\
\hline Contract type** & 89,510 & 0.20 & 0 & 0.40 & 0 & 1 \\
\hline
\end{tabular}

In summary, our estimates were intended to determine - based on the main correlations presented above - whether individual debtors would be able to take out a refinancing loan that would result in a spread decrease sufficient to compensate the debtor for the one-off costs during the remaining term of the loan. We needed the following for the estimate:

- currently charged spread (i.e. the difference between the cost of credit and the 3-month BUBOR),

- spread attainable with a new loan,

- outstanding principal amount,

- length of the remaining maturity,

- refinancing costs.

The biggest problem arising during the estimate is our inability to directly observe the interest rates at which debtors with pre-existing loans would receive a new loan at present. Since without the spread of the refinancing loan it is impossible to determine the spread decrease that could be achieved by the debtors by refinancing, we applied various statistical methods to estimate refinancing spreads for all contracts. That notwithstanding, the information available in the databases at our disposal was still far more limited than what is used by banks in making pricing decisions; consequently, our estimate is surrounded by significant uncertainty.

We applied four different approaches to mitigate the uncertainties surrounding the estimate. On the one hand, this is justified by robustness reasons; on the other hand, we sought to compare the results of the individual estimates that 
complemented one another and had their own advantages and disadvantages. In the estimates, we essentially handled the housing loan and home equity loan portfolios separately. Progressing from the simple to the complex, in the four estimates we approximated the spread of the refinancing loans with the methods described below.

\subsection{Banking sector average spread method}

In the simplest approach, we assigned the average spread of variable-rate mortgage loans disbursed between January 2015 and August 2018 by loan category to all variable-rate mortgage contracts (separately for housing loan and home equity loan products) disbursed between 2004 and 2014, and we took this as the refinancing spread. For the sake of simplicity, in this estimate we assumed that at present, all borrowers with pre-existing mortgage loans could take out a new loan at the typical average spread of the recent period ( 3 percentage points for housing loans and around 4.4 percentage points for home equity loans).

\subsection{Spread-based distribution method}

Separately for housing loans and home equity loans, we calculated the distribution of variable-rate loans disbursed between January 2015 and June 2018 by spread, broken down by percentiles. We assigned the spreads thus received to the percentiles ${ }^{17}$ corresponding to the spreads of the variable-rate mortgage contracts in each purpose category, separately for the loans disbursed in the period 2004-2009 and then for those disbursed in 2010-2014, and took this as the refinancing spread. Thus, for the purposes of this estimate we assumed that the borrower would reside at a similar point of the distribution in the case of newly disbursed loans as in the spread-based distribution of previously disbursed loans; in other words, the borrower's relative risk position did not change in the past years.

\subsection{Median spread method}

In this approach, based on the banks' List of Conditions we assumed that the interest rate/spread is determined primarily by the borrower's income ${ }^{18}$ and the principal amount. Accordingly, within these two dimensions we set up categories for both loan types and examined the median spread of the mortgage loans disbursed between January 2015 and June 2018 as a cross-section of these categories (Table 4 and Table 5). We generated such median values both at the level of the banking sector and at individual bank level.

\footnotetext{
${ }^{17}$ In the case of loans disbursed between 2004 and 2009 the percentiles are based on spreads adjusted for service charges.

${ }^{18}$ The database provided information only on income subject to personal income tax (declared income) and as such, our income data do not contain the value of social transfers and pensions, and we have no information on potential undeclared incomes.
} 


\section{Table 4}

Median spreads of variable-rate housing loans disbursed between January 2015 and June 2018 according to income and contracted amount

\begin{tabular}{|c|c|c|c|c|c|c|}
\hline & \multicolumn{5}{|c|}{ Annual income } \\
\hline & & $\begin{array}{l}600,000- \\
2,400,000\end{array}$ & $\begin{array}{c}2,400,000- \\
4,800,000\end{array}$ & $\begin{array}{c}4,800,000- \\
7,200,000\end{array}$ & $\begin{array}{c}7,200,000- \\
9,600,000\end{array}$ & $9,600,000-$ \\
\hline \multirow{7}{*}{ 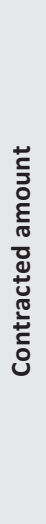 } & $\begin{array}{c}0- \\
500,000\end{array}$ & 4.13 & 4.13 & 4.13 & 4.13 & 4.13 \\
\hline & $\begin{array}{l}500,000- \\
2,000,000\end{array}$ & 3.90 & 3.61 & 3.48 & 3.18 & 3.09 \\
\hline & $\begin{array}{c}2,000,000- \\
4,000,000\end{array}$ & 3.09 & 3.06 & 2.91 & 2.91 & 2.91 \\
\hline & $\begin{array}{c}4,000,000- \\
6,000,000\end{array}$ & 2.91 & 2.91 & 2.91 & 2.90 & 2.65 \\
\hline & $\begin{array}{c}6,000,000- \\
8,000,000\end{array}$ & 2.91 & 2.91 & 2.91 & 2.71 & 2.57 \\
\hline & $\begin{array}{c}8,000,000- \\
10,000,000\end{array}$ & 2.91 & 2.91 & 2.90 & 2.65 & 2.50 \\
\hline & $10,000,000-$ & 2.91 & 2.91 & 2.66 & 2.57 & 2.41 \\
\hline
\end{tabular}

\section{Table 5}

Median spreads of variable-rate home equity loans disbursed between January 2015 and June 2018 according to income and contracted amount

\begin{tabular}{|c|c|c|c|c|c|c|}
\hline & \multicolumn{5}{|c|}{ Annual income } \\
\hline & & $\begin{array}{l}600,000- \\
2,400,000\end{array}$ & $\begin{array}{c}2,400,000- \\
4,800,000\end{array}$ & $\begin{array}{c}4,800,000- \\
7,200,000\end{array}$ & $\begin{array}{c}7,200,000- \\
9,600,000\end{array}$ & $9600,000-$ \\
\hline \multirow{7}{*}{ 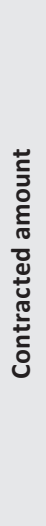 } & $\begin{array}{c}0- \\
500,000\end{array}$ & 5.18 & 5.18 & 5.18 & 5.18 & 5.18 \\
\hline & $\begin{array}{l}500,000- \\
2,000,000\end{array}$ & 5.86 & 5.39 & 4.78 & 4.83 & 4.26 \\
\hline & $\begin{array}{c}2,000,000- \\
4,000,000\end{array}$ & 5.62 & 5.16 & 4.76 & 4.40 & 4.26 \\
\hline & $\begin{array}{c}4,000,000- \\
6,000,000\end{array}$ & 5.31 & 4.79 & 4.54 & 4.34 & 3.98 \\
\hline & $\begin{array}{c}6,000,000- \\
8,000,000\end{array}$ & 4.79 & 4.72 & 4.41 & 4.01 & 3.87 \\
\hline & $\begin{array}{l}8,000,000- \\
10,000,000\end{array}$ & 4.64 & 4.39 & 4.18 & 3.85 & 3.66 \\
\hline & $10,000,000-$ & 4.26 & 4.10 & 3.95 & 3.74 & 3.58 \\
\hline
\end{tabular}


Based on the categories set up according to the outstanding principal amount and the debtor's income, we were able to assign "refinancing spreads" to the old loans as well. We assigned a total of three spreads to each contract:

1) for each contract, the median spread achievable at the debtor's own bank,

2) the median spread achievable at the debtor's bank or in the banking sector as a whole, whichever is lower,

3) the median spread applied by the bank that offers the most favourable spread.

With this distinction, we were trying to factor in the often ad hoc nature of loan refinancing: in the first version, the customer takes into account the offer of his own bank only, in the second version he also considers the offer of "a few other banks" - which we approximated by means of the banking sector average - and finally, in the third version the borrower makes the banks compete in earnest and picks the best spread offered. Our base result is the refinancing ratio which takes the more favourable of two estimates: the own bank and total banking sector spread estimates (Method 2); accordingly, this result is displayed in the summary tables of the results of our estimates (Table 8 and Table 9), while the results of the two remaining estimates are shown separately in Table 10.

\subsection{Linear regression method}

We applied the fourth method to estimate banks' pricing function by means of linear regression. For the purposes of the estimate, we relied on the sample of variable-rate mortgages disbursed between January 2015 and June 2018. Our target variable was the spread over the 3-month BUBOR, while we took into account, as explanatory variables, the log of the contracted amount and the square thereof, the maturity and the square thereof, the log of the average income of debtors and co-debtors, the average age of debtors and co-debtors and the square thereof; moreover, we used binary variables to control for the existence of co-debtors and the contract type. We checked the multicollinearity between the variables with variance inflating factor and did not find it excessive.

We conducted the estimates at the level of the banking sector and at individual bank level by running OLS regressions. We estimated the banking sector model both by controlling for disbursing banks with binary variables and without these control variables. ${ }^{19}$ As a result, we estimated a total of 12 models.

\footnotetext{
${ }^{19}$ In the case of regressions run for each individual bank we essentially allow the partial effect exerted on the spread by specific contractual features to differ across banks, while in the case of the banking sector model estimated with bank fixed effects that is not possible. In the latter model, individual bank features are expressed by bank dummies, but the partial effect of the other variables is uniform for all institutions.
} 
The estimated coefficients of the models of the total banking sector are shown in Table $6 .{ }^{20}$ The direction of the coefficients estimated by the model is consistent with the intuition and with the model results estimated by previous studies (Aczél et al. 2016; Mérö and Vágó 2018). The explanatory power of the models amounts to 44 per cent in the case of the banking sector estimate (based on $\mathrm{R}^{2}$ statistics), and ranges between 8 per cent and 72 per cent in the case of individual bank estimates. At this point, once again we need to draw attention to the uncertainties stemming from the estimate (especially regarding the bank-level models), which can be primarily attributed to the limited scope of the data available. That notwithstanding, for the purposes of our research question we consider the explanatory power of the models sufficient overall, especially in light of the fact that our estimation results are deemed relevant only at the portfolio level.

\begin{tabular}{|c|c|c|}
\hline \multicolumn{3}{|c|}{$\begin{array}{l}\text { Table } 6 \\
\text { Output tables of the linear regressions estimated on the banking sector sample }\end{array}$} \\
\hline Variables & $\begin{array}{l}\text { (1) } \\
\text { Target variable: Spread over } \\
\text { BUBOR }\end{array}$ & $\begin{array}{l}\text { (2) } \\
\text { Target variable: Spread over } \\
\text { BUBOR }\end{array}$ \\
\hline Ln(Contracted amount) & $-1.966 * * *$ & $-2.264 * * *$ \\
\hline Ln(Contracted amount $)^{2}$ & $0.0508 * * *$ & $0.0633^{* * *}$ \\
\hline Maturity & $-0.00657^{*}$ & $0.0117^{* * *}$ \\
\hline Maturity ${ }^{2}$ & $0.000499 * * *$ & $-0.000196 * *$ \\
\hline $\begin{array}{l}\text { Ln(Income/number of } \\
\text { co-debtors) }\end{array}$ & $-0.301 * * *$ & $-0.264 * * *$ \\
\hline Co-debtor & $-0.134 * * *$ & $-0.134 * * *$ \\
\hline Age & $-0.0300 * * *$ & $-0.0159 * * *$ \\
\hline $\mathrm{Age}^{2}$ & $0.000365^{* * *}$ & $0.000209 * * *$ \\
\hline Home equity loan & $1.506^{* * *}$ & $1.451^{* * *}$ \\
\hline Bank dummy & No & Yes \\
\hline Constant & $26.48^{* * *}$ & $26.47^{* * *}$ \\
\hline Number of observations & 77,713 & 77,713 \\
\hline $\mathrm{R}^{2}$ & 0.336 & 0.441 \\
\hline
\end{tabular}

Note: Banks' indicator variables are only included in equation (2); their estimated coefficients are not displayed in our result table for data protection reasons. ${ }^{* * *} p<0.001 ; * * p<0.01 ;{ }^{*} p<0.05$

Having estimated the models, using the estimated coefficients and the information available on previously disbursed variable-rate loans, we predicted "refinancing loan" spreads for the contracts of the old portfolio. Using the results of the various estimation methods, in this case as well, we were able to supply, for each borrower,

${ }^{20}$ For data protection reasons, our result table does not include the output tables of individual bank-level regressions. 
his own bank's "offer", the banking sector's "average offer" and the best bank's "offer". For the purposes of the linear regressions as well, the assumption we considered the most realistic was where the borrower considers his own bank's offer and the banking sector's "average offer", and chooses the one offering the more favourable spread for refinancing his loan. Accordingly, the summary result table shows the results calculated with the spreads of the total banking sector regression equation thus received.

The advantages and disadvantages of the individual methods are presented in Table 7.

\begin{tabular}{|c|c|c|c|c|}
\hline \multicolumn{5}{|c|}{$\begin{array}{l}\text { Table } 7 \\
\text { Advantages and disadvantages of the methods applied to estimate the spread of the } \\
\text { refinancing loan }\end{array}$} \\
\hline & $\begin{array}{l}\text { Banking sector average } \\
\text { spread method }\end{array}$ & $\begin{array}{l}\text { Spread distribution } \\
\text { method }\end{array}$ & $\begin{array}{l}\text { Median spread (based } \\
\text { on loan amount and } \\
\text { income) }\end{array}$ & $\begin{array}{l}\text { Spread estimated by } \\
\text { linear regression }\end{array}$ \\
\hline 岁 & $\begin{array}{l}\text { a reliable way to } \\
\text { double-check the rest } \\
\text { of the estimates }\end{array}$ & $\begin{array}{l}\text { easy to interpret, } \\
\text { intuitive }\end{array}$ & $\begin{array}{l}\text { captures the two most } \\
\text { important } \\
\text { determinants; less } \\
\text { influenced by outliers }\end{array}$ & $\begin{array}{l}\text { the most complex and } \\
\text { comprehensive; } \\
\text { incorporates into the } \\
\text { spread as much } \\
\text { relevant information as } \\
\text { possible }\end{array}$ \\
\hline 岁 & overly simplified & $\begin{array}{l}\text { deems previous and } \\
\text { current spread } \\
\text { distributions identical, } \\
\text { disregards important } \\
\text { features }\end{array}$ & $\begin{array}{l}\text { disregards other } \\
\text { determinants }\end{array}$ & $\begin{array}{l}\text { its point estimate is } \\
\text { surrounded by a high } \\
\text { degree of uncertainty; } \\
\text { influenced by outliers }\end{array}$ \\
\hline
\end{tabular}

We compared the "refinancing" spreads estimated in accordance with the above methods with the actual spread (adjusted for service charges) of the contract and examined whether the difference between the two exceeds the level of the indifference spread decrease associated with the given contract. If yes, we concluded that refinancing the loan is financially worthwhile for the debtor, and if not, then on the contrary, the debt is not worth refinancing.

\section{Estimation results}

Based on our results, it may be possible to refinance around 38-47 per cent of the total portfolio of mortgage loans disbursed prior to 2015 (HUF 651-803 billion) in a financially rewarding manner. Based on the number of contracts, this accounts for 20-29 per cent of the contracts (Table 8). ${ }^{21}$ Examining only the loans converted

\footnotetext{
${ }^{21}$ The stock-based refinancing ratio exceeds the contract-based ratio in the case of all of our results. This is because in the case of longer-term loans - where refinancing may be, ceteris paribus, a more rewarding option - the outstanding debt is typically also higher.
} 
to forint, around 40-48 per cent of the portfolio (HUF 499-603 billion) may be refinanced with financial gain, which covers $20-29$ per cent of these contracts (Table 9).

Besides financial considerations, however, it is questionable whether any bank would be even willing to extend a loan to the debtor. Obstacles include the debtor's advanced age, insufficient income, the transaction's excessively high current loanto-value ratio or the debtor's prior delinquency. Filtering the population by these criteria ${ }^{22}$ revealed that refinancing could be a realistic option for 22-31 per cent of the variable-rate mortgage loan portfolio disbursed prior to 2015 (accounting for 13-21 per cent of the contracts), while in the case of loans converted to forint the corresponding value is $20-28$ per cent (12-19 per cent of the contracts).

The scope of loans that could be effectively refinanced on a market basis may be even more limited in view of the significant share of home equity loans in the total variable-rate mortgage loan portfolio (in particular, in the total portfolio of loans converted to forint). Since the number of home equity loans extended at present is insignificant, we have very limited information on the interest rates at which these loans would be disbursed. Consequently, our estimates pertaining to the refinancing spreads of loans extended in this category are surrounded by greater uncertainty. For all practical purposes, in our estimate we already distinguished between these two product markets, but it is still important to examine the stock of loans that may be refinanced effectively from the aspect of loan type. If we used the extreme assumption that, for lack of market supply, home equity loans cannot be refinanced at all, we would find that, according to our estimate, refinancing could be a viable option for 16-22 per cent of the variable-rate mortgage loan portfolio disbursed prior to 2015 (12-15 per cent of the contracts) and for 14-20 per cent of the loan portfolio converted to forint (9-13 per cent of the contracts). However, we deem this assumption overly excessive; consequently, we consider the ratio of 22-31 per cent (including home equity loans) to be our base result.

${ }^{22}$ We applied the following filter criteria: age above 60 years, current loan-to-value ratio above 100 per cent, annual income below HUF 1.5 million, previous delinquency. 


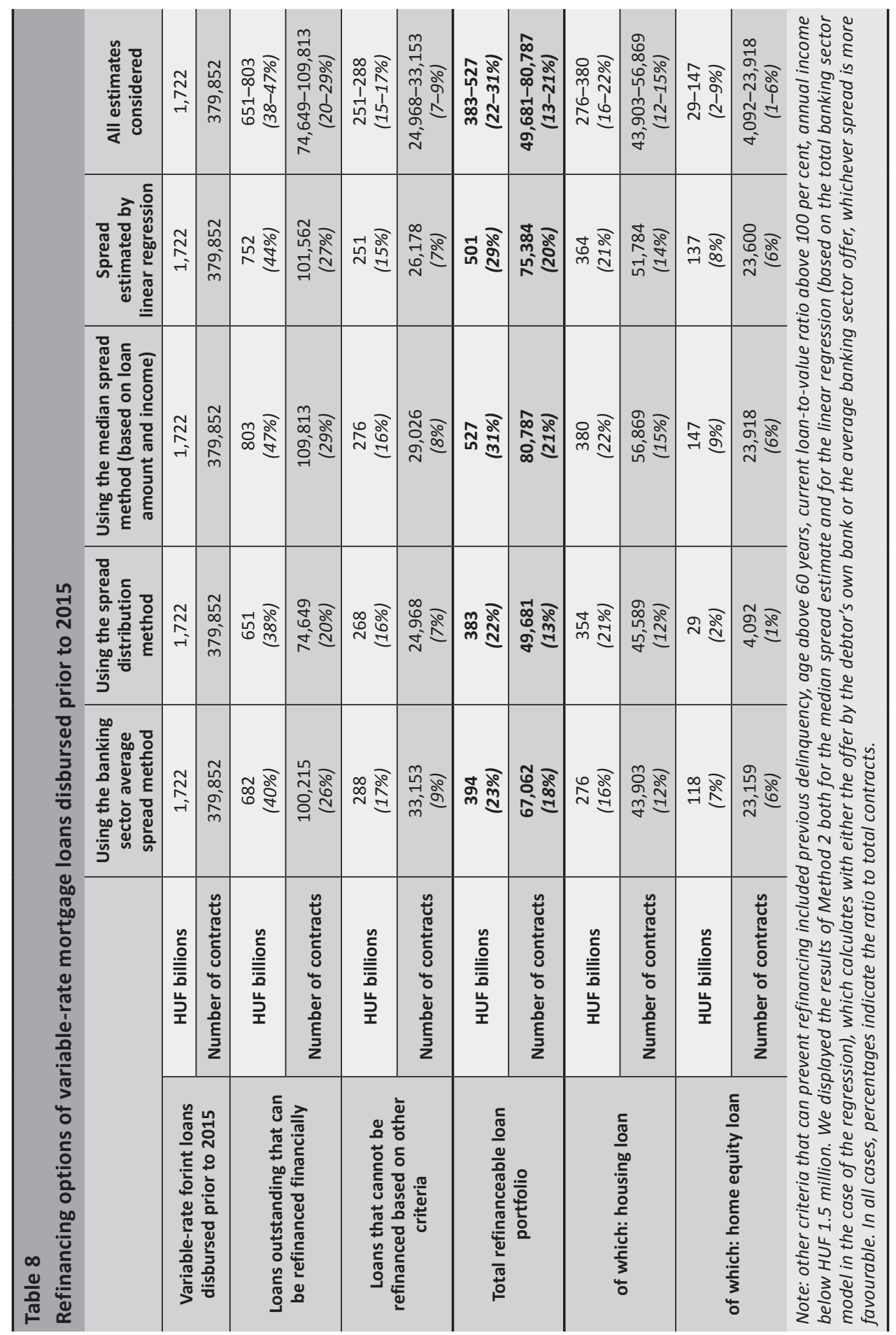




\begin{tabular}{|c|c|c|c|c|c|c|c|c|c|c|c|c|c|c|}
\hline & 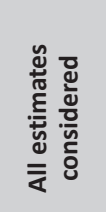 & 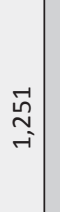 & $\begin{array}{l}\text { N } \\
\text { مै } \\
\text { ஸे }\end{array}$ & 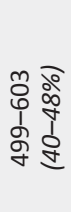 & 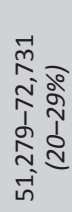 & 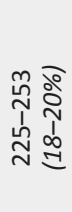 & 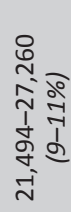 & 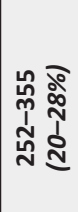 & 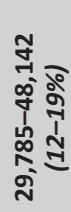 & 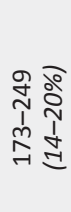 & 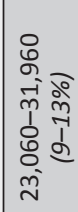 & 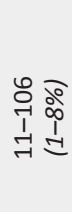 & 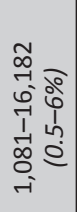 & 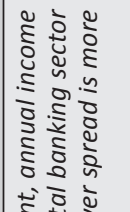 \\
\hline & 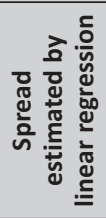 & 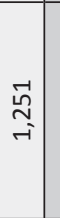 & $\begin{array}{l}\text { N } \\
\text { กิ } \\
\text { ஸे }\end{array}$ & ஸீ & 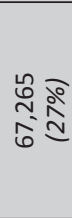 & 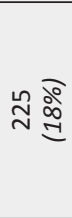 & 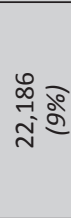 & 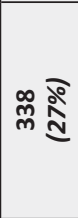 & 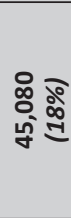 & 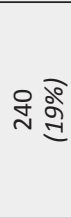 & 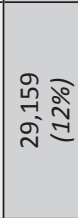 & ๙ & 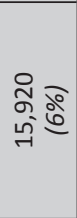 & 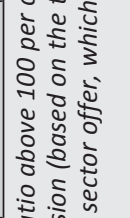 \\
\hline & 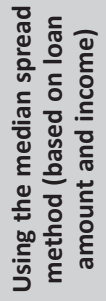 & 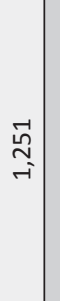 & 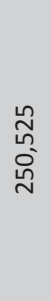 & ח. & $\begin{array}{l}\vec{n} \\
\text { ido } \\
\text { id }\end{array}$ & 政 & 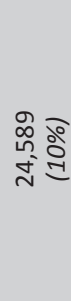 & น & 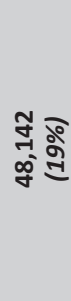 & 일 & $\mid \begin{array}{l}0 \vec{\circ} \\
\stackrel{d}{\vec{m}} \\
\vec{m}\end{array}$ & ర্- ळ & 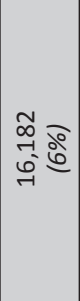 & 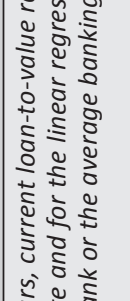 \\
\hline 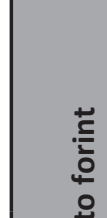 & 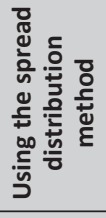 & 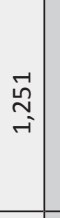 & 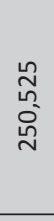 & 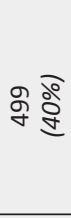 & 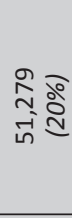 & ঙั ণ্ & $\begin{array}{l}\text { के } \\
\text { जo }\end{array}$ & ฝึ స్ స్ & 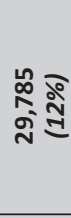 & ๖ & 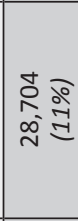 & 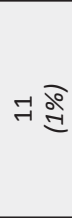 & 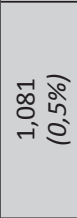 & 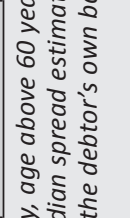 \\
\hline 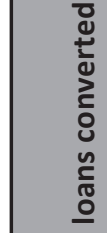 & 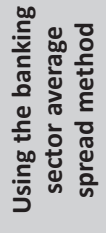 & 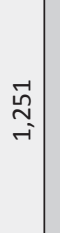 & 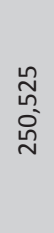 & 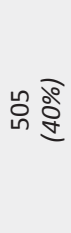 & 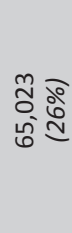 & బู & 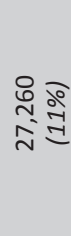 & 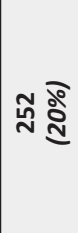 & 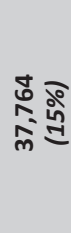 & 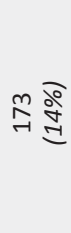 & 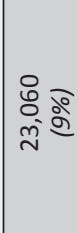 & ৪ बे & 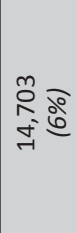 & 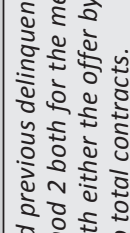 \\
\hline 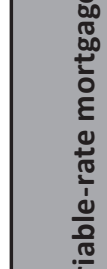 & & 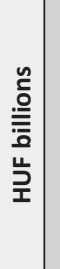 & 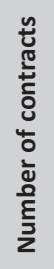 & $\begin{array}{l}\text { 气 } \\
\stackrel{\underline{\underline{0}}}{\overline{\underline{0}}} \\
\text { 泀 }\end{array}$ & 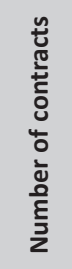 & 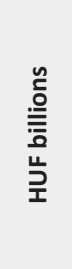 & 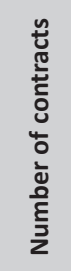 & 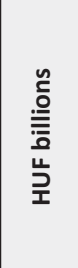 & 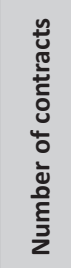 & 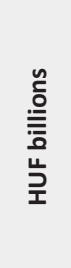 & 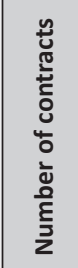 & 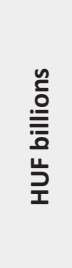 & 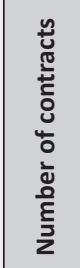 & 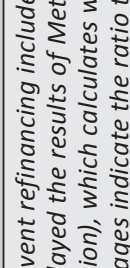 \\
\hline 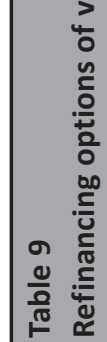 & & 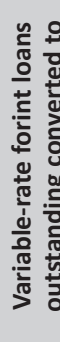 & 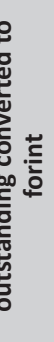 & 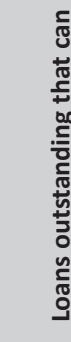 & 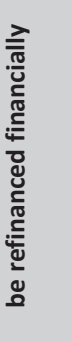 & 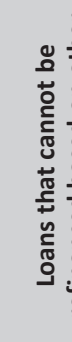 & 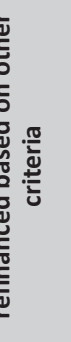 & 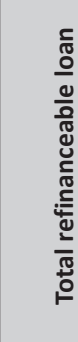 & 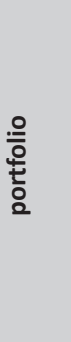 & & 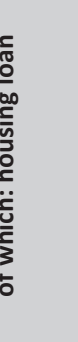 & & 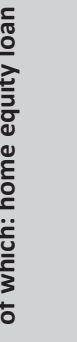 & 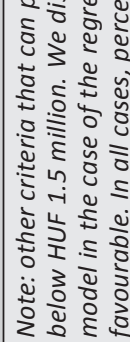 \\
\hline
\end{tabular}


In addition to our benchmark results, in the analyses in which we estimated the spread based on the median spread and by linear regression, we considered it important to examine the change in the portfolio of refinanceable loans (with the constraints already considered) generated by the spread that was constructed based on the offer of the debtor's own bank, the average banking sector offer and that of the bank with the best offer. The results of these hypothetical models pertaining to variable-rate forint loans disbursed prior to 2015 are shown in Table 10. In the case of methods where we assumed that the debtor refinances his loan at his own bank, the results received were similar to those yielded by the methods that also take into account the average banking sector spread and take the best spread of the two. 24-31 per cent (HUF 407-527 billion) of the variable-rate loan portfolio disbursed prior to 2015 was found to be refinanceable, accounting for 17-21 per cent of the contracts. The corresponding ratio for loans converted to HUF is 21-28 per cent (HUF 263-355 billion) at the stock level, representing 14-19 per cent of the loans converted to HUF at the contract level.

If we assume that all debtors refinance their loans at the bank offering the best spread, the refinancing ratio significantly exceeds the corresponding values received in the other models. Based on the results of these methods, 38-43 per cent (HUF 656-746 billion) of the pre-2015 portfolio can be refinanced at the stock level, while this ratio ranges between 27 and 32 per cent according to the number of contracts. Similarly, we received higher refinancing ratios in the case of loans converted to HUF: representing 25-30 per cent of the contracts, 35-40 per cent (HUF 442-503 billion) of the loan portfolio is worth refinancing (and can be refinanced). This result demonstrates that enhancing consumer awareness may offer significant value added in boosting bank competition and at the same time, in reducing households' interest rate risks.

\section{Table 10}

Results of the estimation methods of the spread estimated by the median spread method and by linear regression pertaining to refinancing among variable-rate forint loans disbursed prior to 2015

\begin{tabular}{|c|c|c|c|c|}
\hline & & \multicolumn{3}{|c|}{ Refinanceable loan portfolio (HUF billions) } \\
\hline & & $\begin{array}{l}\text { Method 1: } \\
\text { Own bank } \\
\text { offer }\end{array}$ & $\begin{array}{l}\text { Method 2: } \\
\text { Own bank or average banking } \\
\text { sector offer, whichever better }\end{array}$ & $\begin{array}{l}\text { Method 3: } \\
\text { Best bank } \\
\text { offer }\end{array}$ \\
\hline \multicolumn{2}{|c|}{$\begin{array}{l}\text { Under the median spread method } \\
\text { (based on loan amount and income) }\end{array}$} & $\begin{array}{c}407 \\
(24 \%)\end{array}$ & $\begin{array}{c}527 \\
(31 \%)\end{array}$ & $\begin{array}{c}746 \\
(43 \%)\end{array}$ \\
\hline \multirow{3}{*}{$\begin{array}{l}\text { Spread } \\
\text { estimated } \\
\text { by linear } \\
\text { regression }\end{array}$} & $\begin{array}{l}\text { Total banking sector } \\
\text { regression }\end{array}$ & $\begin{array}{c}445 \\
(26 \%)\end{array}$ & $\begin{array}{c}501 \\
(29 \%)\end{array}$ & $\begin{array}{c}656 \\
(38 \%)\end{array}$ \\
\hline & $\begin{array}{l}\text { Individual bank-level } \\
\text { regressions }\end{array}$ & $\begin{array}{c}435 \\
(25 \%)\end{array}$ & - & $\begin{array}{c}672 \\
(39 \%)\end{array}$ \\
\hline & $\begin{array}{l}\text { All estimation } \\
\text { methods considered }\end{array}$ & $\begin{array}{l}407-445 \\
(24-26 \%)\end{array}$ & $\begin{array}{l}501-527 \\
(29-31 \%)\end{array}$ & $\begin{array}{l}656-746 \\
(38-43 \%)\end{array}$ \\
\hline
\end{tabular}




\section{Conclusion}

In this study, we attempted to estimate what percentage of the variable-rate mortgage loan portfolio could be refinanced on a market basis based on purely financial criteria. Our motivation was provided by the fact that the portfolio of variable-rate mortgage loans is still substantial and that - through the sharp increase in instalments - an extreme interest rate shock would significantly stretch the financial position of many vulnerable households. As MNB (2019) pointed out, many households are not familiar with the concept and basic terms of variable interest rates, which foreshadows that a considerable number of debtors may be unprepared in the event of a potential interest rate increase.

Our estimates were intended to quantify the spread at which borrowers with preexisting variable-rate mortgage loans would be capable of refinancing their loan with a new variable-rate mortgage loan, and to examine whether the difference between the spreads would be sufficient to cover the costs of the refinancing. According to our results, this ratio is relatively low, accounting for 22-31 per cent of the portfolio, with the high level of refinancing costs contributing significantly to this. If we accept the hypothesis that debtors are willing to pay the funding cost increment arising from the interest rate fixation in exchange for the reduced volatility of the instalment amounts, then the estimated ratio may also be indicative of the room available for refinancing with fixed-rate loans on a market basis.

The results presented in the previous section reveal that, in view of the costs of refinancing and the features of the outstanding portfolio, it cannot be expected in the case of a considerable part of the portfolio that the interest rate type will switch to interest rate fixation of over 1 year on a market basis, without external incentives, through consumers' financially aware refinancing decisions. In this regard, it poses a problem that, owing to their potentially low financial awareness and imperfect information, debtors may not necessarily take advantage of the option of refinancing even if they could do so with clear financial gains.

To facilitate a shift toward fixed-rate loans, a regulatory measure has been taken by the Magyar Nemzeti Bank. Under the recommendation issued by the MNB in April 2019 , banks are expected to contact vulnerable debtors - i.e. those holding variablerate mortgage loans with a remaining maturity of over 10 years - in a targeted way and to offer them a switch to fixed interest rates. Based on the recommendation, banks may only charge the costs directly arising from the contract modification to the debtors and may not offer a higher spread to the customer than the current spread specified in the contract.

In our opinion, the MNB's recommendation tackles several problems that currently pose a potential obstacle to refinancing. Firstly, according to the recommendation 
banks contact vulnerable customers (those with long remaining maturity) in a targeted manner and inform them of the phenomenon of interest rate risk. Simultaneously, they offer a fixed-rate refinancing option - or more precisely, a contract modification - to the customers, thereby enhancing their financial awareness in a targeted way. Secondly, by way of the contract modification numerous costs associated with refinancing can be avoided, which significantly improves the chances of the switchover to fixed rates. Thirdly, according to the recommendation, the best practice on banks' part is to offer a spread to customers that is at most identical with the previous spread, and to charge to consumers only the funding cost increment of the reference interest rate corresponding to the duration of the interest rate fixation after the contract modification. This opens up the opportunity for interest rate fixation also for those debtors who would otherwise have access to loans only with higher spreads than previously. Fourthly, the contract modification also enables those debtors to switch to interest rate fixation who would be otherwise unable to take out a new loan due to their age, income or loan-to-value ratio.

\section{References}

Aczél, Á. - Banai, Á. - Borsos, A. - Dancsik, B. (2016): Identifying the determinants of housing loan margins in the Hungarian banking system. Financial and Economic Review, 15(4): 5-44. http://english.hitelintezetiszemle.hu/letoltes/akos-aczel-adam-banai-andras-borsosbalint-dancsik.pdf

Agarwal, S. - Driscoll, J.C. - Laibson, D.I. (2013): Optimal Mortgage Refinancing: A ClosedForm Solution. Journal of Money, Credit and Banking, 45(4): 591-622. https://doi. org/10.1111/jmcb.12017

Agarwal, S. - Rosen, R.J. - Yao, V. (2016): Why Do Borrowers Make Mortgage Refinancing Mistakes? Management Science, 62(12): 3494-3509. https://doi.org/10.1287/ mnsc.2015.2272

Albertazzi, U. - Fringuellotti, F. - Ongena, S. (2018): Fixed rate versus adjustable rate mortgages: Evidence from euro area banks. Banca D'Italia Working Paper, No. 1176. https://doi.org/10.2139/ssrn.3210730

Badarinza, C. - Campbell, J.Y. - Ramadorai, T. (2018): What Calls to ARMs? International Evidence on Interest Rates and the Choice of Adjustable-Rate Mortgages. Management Sciences, 64(5): 2275-2288. https://doi.org/10.1287/mnsc.2016.2629

Bajo, E. - Barbi, M. (2018): Financial illiteracy and mortgage refinancing decisions. Journal of Banking and Finance, 94(C): 279-296. https://doi.org/10.1016/j.jbankfin.2018.08.001

Basten, C. - Guin, B. - Koch, C. (2018): How do banks and households manage interest rate risk? Evidence from mortgage applications and banks' responses. Bank of England Staff Working Paper, No. 733. https://doi.org/10.2139/ssrn.3192943 
Berlinger, E. (2017): Why APRC is misleading and how it should be reformed. Corvinus Economics Working Papers, 5/2017.

Calza, A. - Monacelli, T. - Stracca, L. (2013): Housing Finance and Monetary Policy. Journal of the European Economic Association, 11(1): 101-122. https://doi.org/10.1111/j.15424774.2012.01095.x

Chang, Y. - Yavas, A. (2009): Do Borrowers Make Rational Choices on Points and Refinancing? Real Estate Economics, 37(4): 635-358. https://doi.org/10.1111/j.1540-6229.2009.00258.x

Dancsik, B. (2017): Számít-e a devizahiteles múlt? A lakáshitelkamatok rögzítéséröl szóló döntés vizsgálata mikroszintü adatokon (Analysing the decision of fixing housing loan interest rates on micro-level data: does FX loan history matter?). Közgazdasági Szemle (Economic Review), 64(10): 1030-1055. https://doi.org/10.18414/KSZ.2017.10.1030

ECB (2018): Financial Stability Review, May 2018. European Central Bank.

Ehrmann, M. - Ziegelmayer, M. (2014): Household risk management and actual mortgage choice in the euro area. Working Paper Series, No. 1631. European Central Bank.

Follain, R.J. - Tzang, D. (1988): Interest Rate Differential and Refinancing a Home Mortgage. The Appraisal Journal, 56(2): 243-251.

Hoffmann, P. - Langfield, S. - Pierobon, F. - Vuillemey, G. (2018): Who bears interest rate risk? Working Paper, No. 2176. European Central Bank. https://doi.org/10.1093/rfs/hhy113

Ippolito, F. - Ozdagli, A.K. - Perez-Orive, A. (2018): The transmission of monetary policy through bank lending: The floating rate channel. Journal of Monetary Economics, 95(May): 49-71. https://doi.org/10.1016/j.jmoneco.2018.02.001

Koijen, R.S.J. - Van Hemert, O. - Van Nieuwerburgh, S. (2009): Mortgage Timing. Journal of Financial Economics, 93(2): 292-324. https://doi.org/10.1016/j.jfineco.2008.09.005

Mérő, B. - Vágó, N. (2018): Keresletvezérelt lakáspiaci modell a lakáshitelezést szabályozó makroprudenciális eszközök tanulmányozására (A demand-led model of the housing market for studying the macro-prudential means of regulating housing loans). Közgazdasági Szemle (Economic Review), 65(11): 1115-1153. https://doi.org/10.18414/KSZ.2018.11.1115

MNB (2017): Financial Stability Report, November 2017. Magyar Nemzeti Bank.

MNB (2018a): Growth Report, November 2018. Magyar Nemzeti Bank.

MNB (2018b): Financial Stability Report, November 2018. Magyar Nemzeti Bank.

MNB (2019): Financial Stability Report, May 2019. Magyar Nemzeti Bank. 